\title{
E-Learning as an Alternative Solution for Sustainable Lifelong Education
}

\author{
Maria Cristina ENACHE ${ }^{\star}$
}

\begin{tabular}{l}
\hline \multicolumn{1}{c}{ A R T I C L E I N F O } \\
\hline Article history: \\
Accepted March 2021 \\
Available online April 2021 \\
\hline JEL Classification \\
K22, M21 \\
Keywords: \\
e-learning, e-learning platforms, \\
Lifelong education
\end{tabular}

\begin{abstract}
A B S T R A C T
COVID-19 has affected the lives of people around the world, including educators and students. Both teachers and students need more and more tools to stay connected and engaged in the learning process. Distance learning for the safety of students and their teachers has become a necessity therefore the world is increasingly concerned with finding options for education in online classrooms so that students and teachers can find new ways to continue to focus on learning. Through this article we try to identify tools to provide an online classroom that brings students and teachers together face to face, homework, files, and conversations in one place accessible either on mobile, tablet, computer or browser.
\end{abstract}

(C) 2021 EAI. All rights reserved.

\section{Introduction}

Given the epidemiological situation of the last year, the coronavirus pandemic has pushed many states to close schools for a period that can extend several weeks, teachers in Romania are now challenged to adapt quickly and send an important message: learning continues beyond with school and online tools accessible to all and a lot of determination, we can make progress together and, more than ever, we can encourage students to learn and work independently.

To create successful habits, the management of each educational unit must coordinate the organization of online learning and teachers must communicate with each class, in instant messaging groups organized in advance. All this context means more training time and a greater coordination effort for teachers. Even if the physical classroom interaction will not be fully recovered and not all classes will be organized online, the successful examples of those who have already begun to apply these measures show that no matter how difficult the process is, it is feasible, motivated, and patient. The success of such an approach depends first on all the best possible planning.

The suspension of courses has necessitated the transition to digital platforms through which to homework can be taken. In practice, however, this transition to online courses does not require only the use of an online tool, but the provision of a framework that allows them to be developed online courses effectively. The framework refers to the ability of teachers to use online platforms, and internet access suitable equipment for teachers, plus support for adapting online content. Of it also requires collaboration between teachers from the same school to decide together the schedule adapted to the online environment, mutual support in conducting classes and developing a common methodology for giving homework and exercises, etc.

\section{Conceptual delimitations}

Computer-assisted training is part of the same context: it is a process by which a human subject performs the act of learning through an artificial agent. The artificial agent is usually an educational computer system. An e-learning system is a learning support, which ensures the distribution of all the tools needed to support learning activities, a comprehensive software package, which supports courses provided through the WWW, as well as testing, simulation, discussions or other significant aspects.

E-learning portal - is a website that offers in addition to the standard search engine, and other services such as e-mail, access to information, databases, news and entertainment. The portal offers the possibility to offer access procedures for multiple applications and databases but also a compact layout. In his absence, he would have resorted to separate entities that in principle would have done the same but individually. An e-learning platform is a program product that provides a minimum set of requirements, which allows: 
- the use of a friendly interface adaptable to a constantly changing educational process, characterized by dynamism

- use of a logical support for synchronous and asynchronous communication

- administration and monitoring of information; an accessible management of the educational content

- use of educational content editing modules in various formats

- facilitating offline self-assessment through asynchronous procedures and online assessment through synchronous procedures of assimilated knowledge

- a continuous training program with partial verifications throughout the educational process

- assisting users in using the educational product

- recording the feedback regarding the quality of the educational services offered, as well as the quality of the educational platform.

Information technology, with its main exponent - the computer, entered the field of education, initially as an object of study, then as an auxiliary tool for increasing productivity and finally even as a tool for education and training. The characteristics that highlight the educational system currently are:

- accentuated specialization

- accelerated obsolescence of knowledge in the top fields

- permanent training, increasing the number of those who want to follow a training system, of the highest possible level

- $\quad$ slower growth of training capacities

- increasing the possibilities of information.

All this makes the computer an indispensable tool in modern education systems. Computer-assisted education refers to the use of the computer as the main element of the educational environment, for the purpose of learning. Although the written text remains the main means of transmitting information, it is no longer printed on paper, as in the period of education based exclusively on textbooks. It is displayed today on computer screens, on the screens of PDA devices or mobile phones. Computers bring several new elements that have the role of improving the educational process: visual elements (static and dynamic images) and auditory, interactive references, tactile, olfactory or neurological stimuli. Training with the help of technical means, which was later done with the assistance of a computer, is a field in constant development. For this reason, the identification of its landmarks and characteristics can be done only from a historical perspective. This approach will be adopted in the first part of this paper, highlighting the characteristic elements of the most important trends and guidelines that marked the development of the field of training.

\section{Strategy, methodology and technology}

The evolution of society has reached the point where the transmission of information for training can no longer be done without the use of electronic computer in the conditions in which it becomes a natural component of public or domestic services. The theoretical solution materialized through the development of standards for the use of personal computers, the problem being thus transposed in the field of education. Thus, was born the idea that computing equipment could be used in the educational process. The software systems dedicated to learning that were developed and implemented in the following years were later called "classics". "Classical" training systems, which do not use artificial intelligence techniques, and which implement a pedagogical strategy based on the gradual acquisition of sequences of instructional content, continue to be developed and used with great success even today.

Table 1. Differences in strategy, methodology and technology between different types of learning

\begin{tabular}{|l|l|l|}
\hline \multicolumn{1}{|c|}{ Strategy } & \multicolumn{1}{|c|}{ Methods } & Technology \\
\hline $\begin{array}{l}\text { Traditional education: "Learn } \\
\text { and apply practically." }\end{array}$ & $\begin{array}{l}\text { Experience-based education: laboratories, } \\
\text { classrooms, case studies, guidance, expert } \\
\text { presentations. }\end{array}$ & Face-to-face \\
\hline $\begin{array}{l}\text { Collaborative education: } \\
\text { "Advise and apply } \\
\text { practically". }\end{array}$ & $\begin{array}{l}\text { Collaborative education: online virtual } \\
\text { classes, virtual laboratories, collaborative } \\
\text { sessions, video conferences, group work. }\end{array}$ & Collaborative \\
\hline $\begin{array}{l}\text { Education through } \\
\text { interaction: "Study and test". }\end{array}$ & $\begin{array}{l}\text { Interactive education: computer-assisted } \\
\text { learning modules, interactive games, } \\
\text { simulations, modeling. }\end{array}$ & Multimedia \\
\hline $\begin{array}{l}\text { Internet education: "Read, } \\
\text { see, listen". }\end{array}$ & $\begin{array}{l}\text { Web courses, e-books, web conferences, } \\
\text { documentation, training films, etc. }\end{array}$ & Internet \\
\hline
\end{tabular}


E-learning is a component of the technology-based model. The term was taken from Anglo-Saxon literature. In a minimal form, we could designate e-learning as the totality of educational actions carried out with modern computer means. We could conclude that this concept of e-learning would designate all the educational situations in which the means of information and communication technology are used. Between the current computer-assisted training systems, a fairly clear typological differentiation can be observed if the combination of two criteria is taken into account: the internal architecture of the training system; the purpose for which the training system was designed.

Starting from the architecture and the purpose, we can highlight a classification of them in the following categories of computer-assisted training systems:

- $\quad$ online user manuals - Online software manuals have the following defining features:

$\circ$ is an integral part of any software product, accompanying it in any format

○ by the purpose for which they are developed they are meant to support the user in his approach to acquire skills necessary for carrying out well-specified computer activities

- provides support for imitation learning and promotes the transfer of competence

○ it uses hypertext to present informational content

- user can use online manuals to learn how to use a computer product in carrying out activities that were not provided by its creators.

- $\quad$ hypermedia systems - Hypermedia systems for assisted learning:

○ it combines hypertext with multimedia (graphics, animation, sound, interactive objects)

- as a training method it uses the guidance of the presentation, the instructional content, being able to be made available also in the form of autonomous systems delivered on different memory supports, which can be used by one person at a time,

○ the topics approached can be from various fields: computer science, economics, chemistry, physics, medicine, geography, language learning, cultural-artistic field (painting, music),

o use it as an instructional method to guide the user on the instructional route,

- $\quad$ classic tutorials - Classic tutorials can be described as follows:

○ are elaborated starting from well-specified instructional objectives,

○ the knowledge that is delivered to the user to be learned is explicitly presented after which a process of fixing the knowledge takes place,

- the verification of the notions in the lessons is done through questions, exercises, problems, by implementing learning by solving problems as a pedagogical method,

- most of the time, Web technology ensure access to instructional content,

- are ubiquitous because most complex software systems are accompanied by classic tutorials, designed to train how to use the computer system.

We can summarize this section through Figure 1, which highlights the methods of presentation, training and evaluation, as well as the type of interaction with the user for each type of computer-assisted training presented.

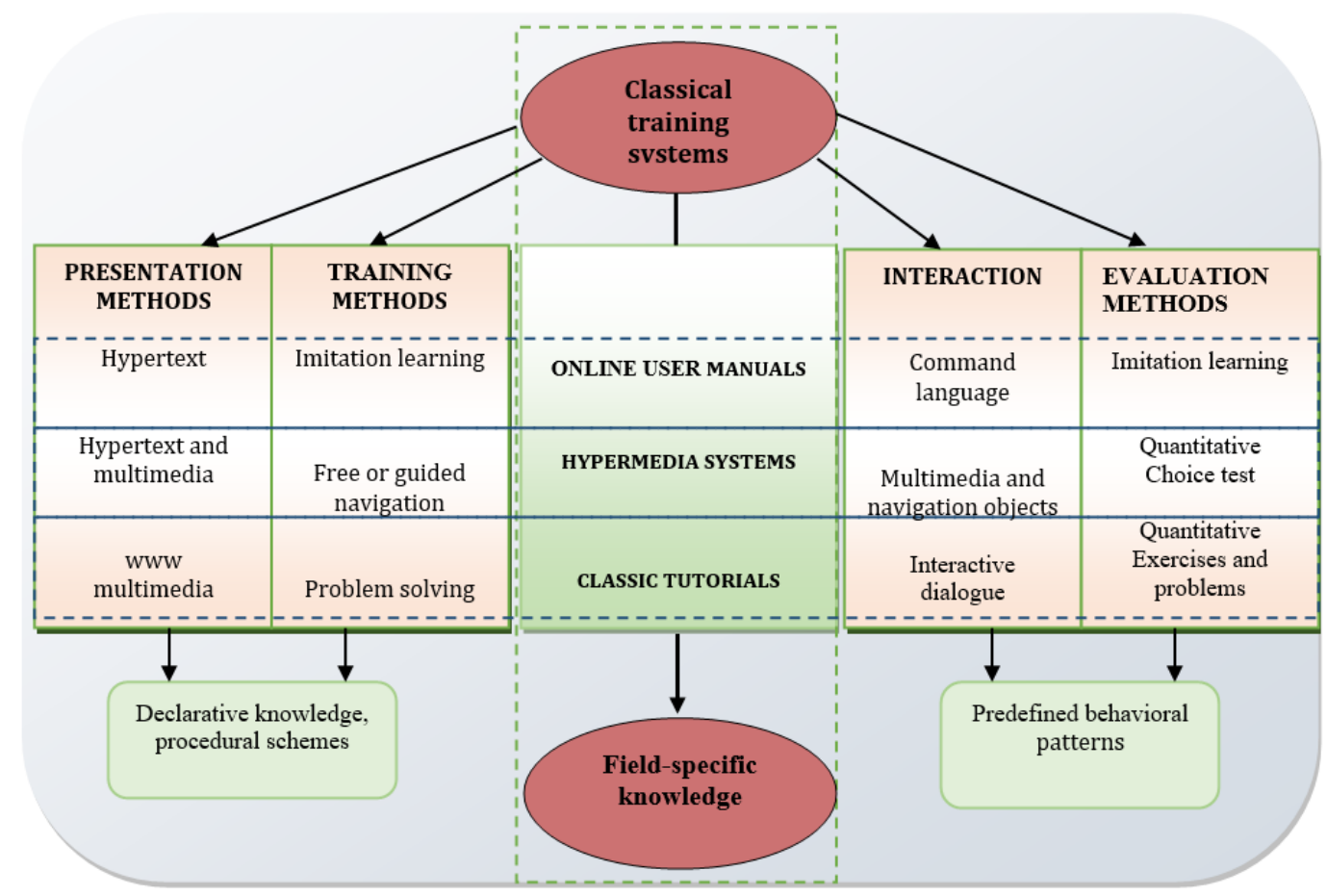

Figure 1. Types of computer aided training systems 
The development directions following the pandemic made the e-learning paradigm of the educational process in the information society to know at least three forms of manifestation: distributed classes, independent education, and open distance learning.

- Distributed Classroom Model - The distributed classroom model extends the classic model of classroom courses to courses with a group of students in multiple locations using interactive telecommunications technologies. Such a model leads to the formation of a study group in which some of the students are in the classroom and another part at a distance. The number of locations of the course participants can vary from 2 (point-to-point courses) to 5 or more (point-to-multipoint courses). In terms of classroom support technologies, these are video-bidirectional dialogue, video-unidirectional and audio-bidirectional dialogue, audio conferencing, and video conferencing. Support technologies that can be used outside of class hours would be telephone, fax, classic mail and personal computer for e-mail, reading instructional materials, audio or video conferences, access to the virtual library or the materials offered.

- The independent learning model focuses on the learner, who is released from the obligation to be in a certain place at a certain time. He receives instructional materials, course materials and the opportunity to have direct access to an instructor / teacher who will answer questions, guide him, and evaluate his work. In such a form there are no class hours, and they study independently. You can interact with the teacher and in some cases with other colleagues. Support technologies that can be used outside of class hours would be telephone, voice mail, classic mail, and personal computer for e-mail, reading instructional materials, audio or video conferences, access to the virtual library or the materials offered. Course materials can be offered in many formats: paper, diskette, CD-ROM, videotapes, etc. The realization of the materials is done by involving different specialists in the field, pedagogues, linguists or other specialized persons.

- $\quad$ The distance learning model involves the use of printed courses and media materials to allow learners to study when and where they want. Students meet regularly in groups in a certain location so that the teacher can give an hour of class through interactive technologies, like the distributed class model. Course materials can be offered in many formats: paper, diskette, CD-ROM, videotapes, etc. In terms of classroom support technologies, these are video-bidirectional dialogue, video-unidirectional and audiobidirectional dialogue, audio conferencing and video conferencing. Support technologies that can be used outside of class hours would be telephone, fax, classic mail and personal computer for e-mail, reading instructional materials, audio or video conferences, access to the virtual library or the materials offered.

The main attributes of the stated forms of expression are detailed in Table 2.

Table 2. Comparison between the forms of expression of e-learning

\begin{tabular}{|c|c|c|c|}
\hline & $\begin{array}{c}\text { Distributed Classroom } \\
\text { Model }\end{array}$ & $\begin{array}{c}\text { The independent learning } \\
\text { model }\end{array}$ & Distance learning model \\
\hline \multirow[b]{2}{*}{ Characteristics } & $\begin{array}{l}\text { It combines real } \\
\text { communications } \\
\text { virtual ones once a week } \\
\text { being necessary to meet in } \\
\text { a physical space. }\end{array}$ & $\begin{array}{l}\text { There are no classes, and } \\
\text { they study independently. } \\
\text { Can interact with the } \\
\text { teacher and in some cases } \\
\text { with other colleagues. }\end{array}$ & $\begin{array}{l}\text { Students meet regularly in } \\
\text { groups in a certain } \\
\text { location so that the teacher } \\
\text { can give an hour of class } \\
\text { through interactive } \\
\text { technologies, like the } \\
\text { distributed class model. }\end{array}$ \\
\hline & $\begin{array}{l}\text { The number of locations of } \\
\text { the course participants can } \\
\text { vary from } 2 \text { (point-to- } \\
\text { point courses) to } 5 \text { or } \\
\text { more (point-to-multipoint } \\
\text { courses). }\end{array}$ & $\begin{array}{l}\text { Course materials can be } \\
\text { offered in many formats: } \\
\text { paper, diskette, CD-ROM, } \\
\text { videotapes, etc. } \\
\text { The realization of the } \\
\text { materials is done by } \\
\text { involving different } \\
\text { specialists. }\end{array}$ & $\begin{array}{l}\text { Course materials can be } \\
\text { offered in many formats: } \\
\text { paper, diskette, CD-ROM, } \\
\text { videotapes, etc. }\end{array}$ \\
\hline $\begin{array}{l}\text { Support } \\
\text { technologies } \\
\text { for classes }\end{array}$ & $\begin{array}{lll}\text { - } & \text { bidirectional } & \text { video } \\
\text { dialogue } & \\
\text { - } & \text { one-way } \\
\text { dialogue } & \text { video } \\
\text { - } & \text { bidirectional audio } \\
\text { dialogue. } & \\
\text { - } & \begin{array}{l}\text { audio conferences. } \\
\text { video conferencing. }\end{array}\end{array}$ & $\begin{array}{l}\text { none because there are no } \\
\text { classes. }\end{array}$ & $\begin{array}{ll}\text { - } & \text { bidirectional video } \\
\text { dialogue. } & \\
\text { - } & \text { unidirectional video } \\
\text { dialogue. } & \\
\text { - } & \text { bidirectional audio } \\
\text { dialogue. } & \\
\text { - } & \text { audio conferences. } \\
\text { - } & \text { video conferencing. }\end{array}$ \\
\hline
\end{tabular}




\begin{tabular}{|c|c|c|c|}
\hline & $\begin{array}{c}\text { Distributed Classroom } \\
\text { Model }\end{array}$ & $\begin{array}{c}\text { The independent learning } \\
\text { model }\end{array}$ & Distance learning model \\
\hline $\begin{array}{l}\text { Out-of-class } \\
\text { support } \\
\text { technologies }\end{array}$ & $\begin{array}{ll}\text { - } & \text { telephone } \\
\text { - } & \text { fax } \\
\text { - } & \text { classic mail } \\
\text { - } & \text { personal computer. }\end{array}$ & $\begin{array}{ll}- & \text { telephone } \\
\text { - } & \text { voice mail } \\
\text { - } & \text { classic mail } \\
\text { - } & \text { personal computer. }\end{array}$ & $\begin{array}{l}\text { - telephone } \\
\text { - voice mail } \\
\text { - personal computer. }\end{array}$ \\
\hline
\end{tabular}

The application of new information and communication technologies in the context of widespread use of the Internet can result in increased creativity and improved teamwork, changing the role of the instructor / teacher, reducing negative influences among students, which is reflected in intimidation or frustration. New technologies are changing the perspective on e-education, as they are already complementing the education system with modern learning methodologies specific to the information society, without aiming to replace traditional education systems, but to strengthen the learning process.

\section{Conclusions}

Along with teachers of various specializations who deal with student instruction, in the design of such web-based training systems there must be a whole team of psycho-pedagogues and computer scientists to oversee the structuring of all materials. With the evolution of media suitable for storing educational content and the emergence of management components in organizing the educational process, it was necessary to define new actors derived from the category of trainer and add a participant dedicated to the management of a study program.

\section{References}

1. Pamfilie, R., Onete, B., Pleşea, D.\& Maiorescu, I. (2008). Quality in E-learning, Special issue of Quality - Access to Success, 92 , 46-51

2. Pleşea D., Onete B., Maiorescu I. \& Dina N. (2011). A Multimedia Solution for Distance Learning of Practical Skills in Commodity Science, Proceedings of the 7th International Scientific Conference "eLearning and Software for Education", Bucharest, vol. II, 549-552

3. Roșca I. Gh., Stoica M., Ghilic-Micu B., Societatea informaţională. E-Serviciile, Editura Economică, București, 2006

4. Alrawi, K., Ekbia H. \& Jaber, K. (2008). A New Marketing Strategy for E-Commerce - The Gulf Region Experience, Global Business Review, 9(2), 273-286

5. American Society for Training and Development, www.astd.org

6. Free and Open Source Software Directory of Key Terms,

http://europa.eu.int/information_society/activities/opensource/doc/pdf/key_terms.pdf

7. European Commission, Education and Training, http://europa eu.int/comm/education/eLearning

8. http://constructivist-education.blogspot.com

9. EDEN: European Distance and E-Learning Network: http://www.eden-online.org/eden.php 